\title{
An Assessment of Water Quality Parameters at the Cerrillos Reservoir, Ponce, Puerto Rico in the Aftermath of Hurricane Maria
}

\author{
Yashira Marie Sánchez-Colón ${ }^{1 *}$, Javier Alejandro Chévere-Del Río1, \\ Nichole Marie Sánchez-Guzmán², Fred Charles Schaffner ${ }^{3}$ \\ ${ }^{1}$ Public Health Program, Ponce Health Sciences University, Ponce, Puerto Rico \\ ${ }^{2}$ Puerto Rico Department of Health, San Juan, Puerto Rico \\ ${ }^{3}$ School of Science and Technology, Universidad Ana G Méndez, Gurabo Campus, Gurabo, Puerto Rico \\ Email: ^ysanchez@psm.edu, jchevere13@stu.psm.edu, nichole.sanchez@upr.edu,fcspr@caribe.net
}

How to cite this paper: Sánchez-Colón, Y.M., Río, J.A.C.-D., Sánchez-Guzmán, N.M. and Schaffner, F.C. (2022) An Assessment of Water Quality Parameters at the Cerrillos Reservoir, Ponce, Puerto Rico in the Aftermath of Hurricane Maria. Journal of Water Resource and Protection, 14, 35-49. https://doi.org/10.4236/jwarp.2022.141003

Received: December 21, 2021

Accepted: January 18, 2022

Published: January 21, 2022

Copyright $\odot 2022$ by author(s) and Scientific Research Publishing Inc. This work is licensed under the Creative Commons Attribution International License (CC BY 4.0).

http://creativecommons.org/licenses/by/4.0/

(c) (i) Open Access

\begin{abstract}
Maintaining the water quality of lakes and reservoirs is part of the 2030 Agenda for Sustainable Development, an initiative promoted by the United Nations, including anthropogenic and natural factors that may influence water quality. The water reservoirs of Puerto Rico were built in watersheds to provide runoff control and for primary uses. The Cerrillos Reservoir is one of the largest water reservoirs in southern Puerto Rico, and is used as a source of potable water and for recreational activities. After hurricane Maria, in September 2017, many communities were without public water service and have obtained their drinking water from local rivers or their tributaries, without filtration or purification treatment. This research explored the physical-chemical parameters of Cerrillos Reservoir's surface water from May 2018 to January 2019. The objective of the present study is to assess seasonal variations in surface water quality with respect to physical (temperature, turbidity, and conductivity), chemical (nutrient concentrations: (Phosphorus (P) (Soluble Reactive Phosphorus, phosphate, or orthophosphate) and Nitrogen (N) (nitrate, nitrite, and ammonia)), $\mathrm{pH}$, and dissolved oxygen), and biological (total coliforms and Escherichia coli) parameters. Results suggest that Cerrillos Reservoir did not exceed the parameters of temperature, turbidity, conductivity, $\mathrm{pH}$ and DO, established by the Puerto Rico Department of Natural and Environmental Resources (PRDNER). The reservoir showed a stable trophic state in relation to inorganic phosphorus and nitrogen as $\mathrm{N}$ and $\mathrm{P}$ concentrations did not increase sufficiently to disrupt this ecosystem. However, total coliforms exceeded the maximum parameter $(23 \mathrm{MPN} / 100 \mathrm{~mL}-994$ MPN/100mL) established for the Puerto Rico Department of Natural and En-
\end{abstract}


vironmental Resources and are likely to be the results of the disruption caused

by hurricane Maria.

\section{Keywords}

Cerrillos Reservoir, Water Quality, Puerto Rico, Post Hurricane Maria

\section{Introduction}

Surface waters (lakes, reservoirs, rivers, oceans, and creeks) are protected by the US federal Clean Water Act in order to mitigate the degradation of the water quality of United States. The Clean Water Act requires each state to submit a report (305(b)) about the quality of the state's surface and groundwater and a state's list (303(d)) of impaired and threatened waters to the Environmental Protection Agency, every two years. Surface water quality is impacted by both natural and anthropogenic activities that can affect biological and physico-chemical properties of water. Physico-chemical parameters include $\mathrm{pH}$, color, odor, taste, heavy metals, nutrient concentrations (phosphorus and nitrogen), sulphate concentrations, cations and anions, temperature, conductivity, hardness, turbidity, total dissolved solids (TDS), acidity, chemical oxygen demand (COD), biological oxygen demand (BOD) and dissolved oxygen (DO) [1] [2]. Biological contamination includes pathogenic bacteria, viruses and parasites that can cause various water-borne diseases like diarrhea, cholera, malaria, skin diseases, typhoid, dysentery, giardia, hepatitis, dysentery, bacillus, schistosomiasis, gastrointestinal disease, respiratory conditions, and others [2] [3].

Anthropogenic factors that influence water quality include domestic sewage, deforestation, industrialization, mining, pesticides, herbicides and fertilizers, plastics and polyethene bags, population growth, urbanizations, weak management system (e.g., toxic waste disposal, sewage leakages, oil spillage and drilling activities) [3] [4] [5]. Natural factors that influence water quality include geology, vegetation, morphology and catchment characteristics, atmospheric deposition associated with precipitation and weathering process [1] [5].

The 2030 United Nations Agenda for Sustainable Development [6] contains 17 Sustainable Development Goals (SDGs), and of these, SDG Goal 6 "Clean Water and Sanitation" focuses on the role of water and sanitation in the development of economic, social, and environmental dimensions [7]. The actions to achieve the sustainable development of surface freshwater, mainly lakes and reservoirs, strongly interlink with nine SDGs (Goal 1: No poverty; Goal 2: End hunger; Goal 3: Good health and well-being; Goal 6: Clean Water and Sanitation; Goal 7: Affordable and clean energy; Goal 8: Decent work and economic growth; Goal 13: Climate action; Goal 14: Life below water; and Goal 15: Life on land) [7].

Lakes are naturally occurring low points in the landscape that contain standing water, predominantly in the form of year-round open water habitat [8]. While reservoirs are defined as any human-made lake whether it be embedded within a 
river network or not and may or may not have an outflow control structures or a dam [8]. Reservoirs provide multiple benefits to society, allowing power generation, providing biodiversity, and enhancing recreation opportunities, navigation, and offering protection against damaging floods because they regulate river flow and domestic, industrial and irrigation use [7] [8] due to their storage function. Reservoirs are constructed with a dam for storing water during rainy seasons and use it in the drought seasons [9] [10] in response to water crises, but this infrastructure will alter the status of rivers by changing their connectivity and flow regime [11].

Climate change is one important factor that affect the aquatic ecosystem functioning, because it impacts the hydrologic regime and changes air temperature [1] [12], and therefore water temperature. Variations in water temperature change most physical, chemical, and biological properties of water [13].

Hurricane Maria was a category 5 hurricane that devastated Puerto Rico in September 2017. After hurricane Maria, many communities in Puerto Rico were without public water service and obtained their drinking water directly from local lakes, reservoirs, rivers or their tributaries without any filtration or purification treatment, increasing the conditions related to unclear water, such as vomiting, diarrhea, conjunctivitis, scabies, asthma, and leptospirosis [14]. Sewage treatment plants were out of service allowing the leaching of raw sewage or other contamination into drinking water resources [15].

In the watershed of our study site, the Cerrillos Reservoir (Lago Cerrillos) in southern Puerto Rico about $6 \mathrm{~km}$ northeast of the municipality of Ponce, for example, the potential sources of pollution are agriculture, minor industrial point source, collection system failure, onsite wastewater systems, urban runoff and storm sewers and surface mining [16] [17]. The Puerto Rico Department of Natural and Environmental Resources (PRDNER) establishes Water Quality Standards (WQS) for the waters of Puerto Rico according to the designated uses to be protected.

Water quality data for this site before hurricane Maria in September of 2017 are scarce. However, from February to December 2010, Cerrillos Reservoir presented the following water quality: $28.2^{\circ} \mathrm{C}$ for temperature, $8.61 \mathrm{mg} / \mathrm{L}$ for dissolved oxygen (DO), 24.2 NTU for turbidity, 8.5 for $\mathrm{pH}, 197.9 \mu \mathrm{S} / \mathrm{cm}$ for conductivity and had overall very low nutrient concentrations [18]. The Puerto Rico 2016 305(b) and 303(d) Integrated Report suggested that the causes of impairment at the Cerrillos Reservoir were low dissolved oxygen and $\mathrm{pH}$ [16], and excessive coliforms were not reported.

From October to December 2017, faculty and students from the Public Health Program at Ponce Health Sciences University in Ponce, Puerto Rico, provided educational interventions to improve people's understating of key concepts after a disaster or emergency. The educational interventions included information about water management and disinfection, handling, and use of a water purification system for disaster relief, personal hygiene, hand washing, and proper handling of food safety and sanitation. Until December 2017, we had impacted around 
2871 people (including 20 communities, 10 shelters and 19 schools), mainly from the southern region of Puerto Rico. Also, we analyzed total coliforms and Escherichia coli (E. coli) in water surface (rivers or their tributaries) of communities without public water service. In May 2018, we began regular monitoring to assess the water quality of Cerrillos Reservoir.

The Objective of the present work is to assess seasonal variations in surface water quality with respect to physical (temperature, turbidity, and conductivity), chemical (nutrient concentrations: (Phosphorus (P) (Soluble Reactive Phosphorus, phosphate, or orthophosphate) and Nitrogen $(\mathrm{N})$ (nitrate, nitrite, and ammonia)), pH, and dissolved oxygen), and biological (total coliforms and Escherichia coli) parameters and thereby characterize conditions at Cerillos Reservoir in the aftermath of hurricane Maria.

\section{Materials and Methods}

\subsection{Description of the Study Site}

Cerrillos Reservoir is one of the largest reservoirs in south Puerto Rico. It is used for drinking water, recreational activities and provides flood control. Cerrillos Reservoir dam is situated in the municipality of Ponce in southern Puerto Rico (Figure 1). The construction of the Cerrillos dam began in 1984 and was

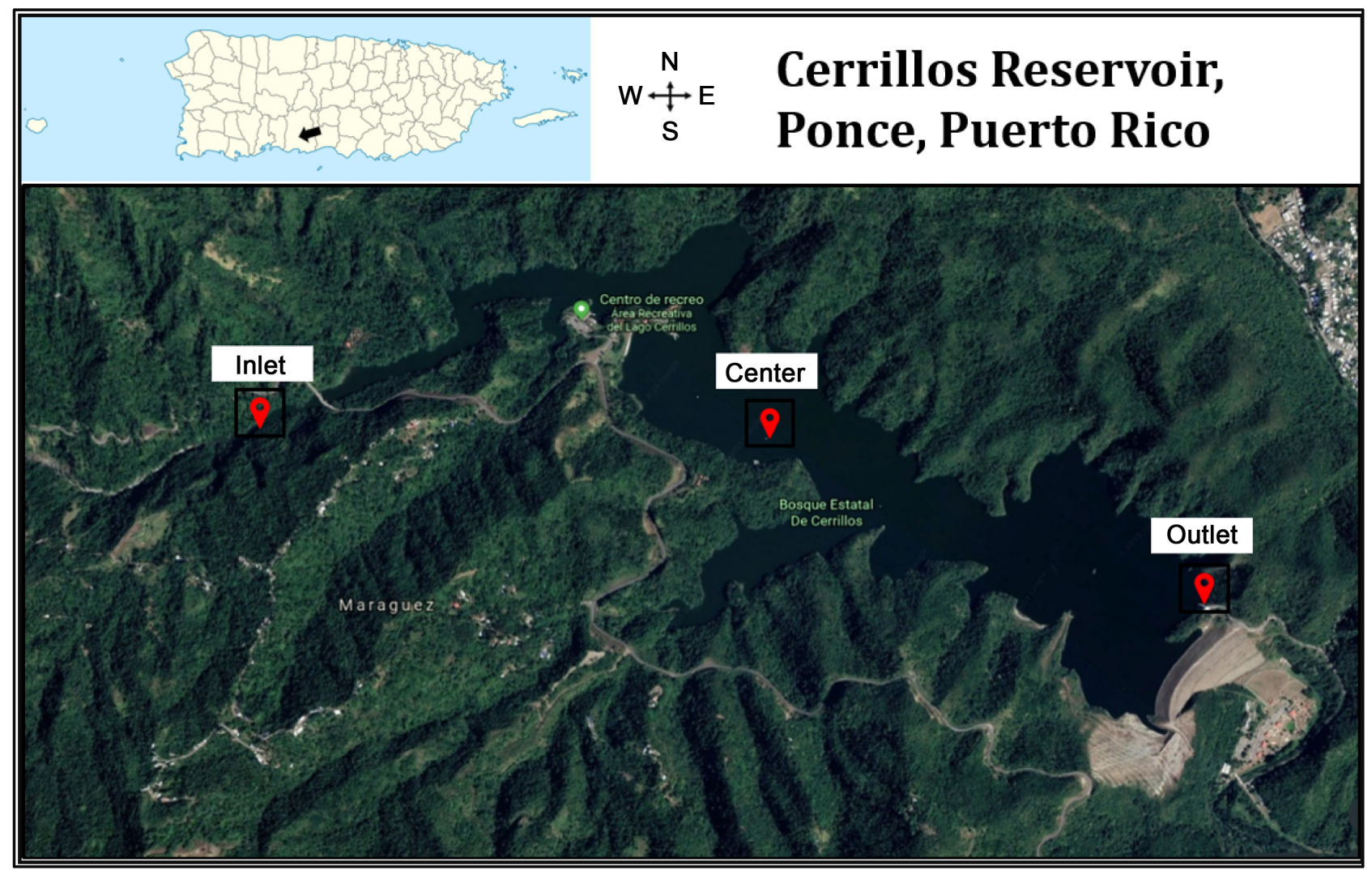

Figure 1. Location of Cerrillos Reservoir in the municipality of Ponce, Puerto Rico. Sampling points of Cerrillos Reservoir: the "Inlet" corresponded to the entry of the main river that provides water to the Cerrillos Reservoir; the "Center" was located at the approximate midpoint of the reservoir (the deepest part of the reservoir); and the "Outlet" was located near the dam. 
completed in 1991 by the US Army Corp of Engineers [19]. The dam is a rockfill structure with a height of 98.45 meters and a length of 473.96 meters [19]. The reservoir receives streamflow from the Cerrillos River and an unnamed creek that enters Cerrillos Reservoir [19]. Cerrillos Reservoir had an original storage capacity of 38.03 million cubic meters at maximum conservation pool elevation of 174.65 meters above mean sea level and a drainage area of 174.65 square kilometers [19]. The available capacity of this reservoir is rapidly diminishing due to sedimentation.

\subsection{Sampling and Processing}

Water samples were collected in triplicate at surface from the inlet, center, and outlet of the Cerrillos Reservoir (Figure 1). The inlet corresponded to the entry point of the main river that provides water to the Cerrillos Reservoir. The center was located at a midpoint of the reservoir, at the deepest part of the reservoir. The outlet was located near the dam. Sampling occurred once or twice per month from May 2018 to January 2019. Phosphorus (P) (Soluble Reactive Phosphorus (SRP)), Nitrogen $(\mathrm{N})$ (nitrate $\left(\mathrm{NO}_{3}^{-}\right)$, nitrite $\left(\mathrm{NO}_{2}^{-}\right)$and ammonia $\left(\mathrm{NH}_{3}\right)$ ), temperature $\left({ }^{\circ} \mathrm{C}\right)$, turbidity $(\mathrm{cm})$, conductivity $(\mu \mathrm{S} / \mathrm{cm}), \mathrm{pH}$ and dissolved oxygen $(\mathrm{DO}, \mathrm{mg} / \mathrm{L})$ were measured in the field for each sampling event. Instruments used to measure these parameters were a $\mathrm{HACH}$ SL1000 portable colorimeter for SRP, $\mathrm{NO}_{3}^{-}, \mathrm{NO}_{2}^{-}, \mathrm{NH}_{3}$, and $\mathrm{pH}$; HACH $2100 \mathrm{Q}$ for turbidity. Temperature, conductivity and DO were determined with a YSI 556 Water Quality Sonde. A Garmin GOS Oregon 650T was used for sample site identification.

Rainfall data were recorded from June 2018 to January 2019 with a rain gauge located at the Department of Natural and Environmental Resources office at the Cerrillos Reservoir. All samples for biological parameters (total coliforms and Escherichia coli ) were collected in glass bottles and stored at a low temperature and analyzed within 24 hours using the Colilert test and Quanti-Tray System. The most probable number (MPN) was determined for total coliforms while $E$. coli was assessed as presence/absence.

\subsection{Statistical Analyses}

Mean SRP, nitrate, nitrite, ammonia, temperature, turbidity, conductivity, $\mathrm{pH}$ and $D O$ values were calculated for each sample (triplicate sampling, $n=3$ for each sample). ANOVA (Analyses of Variance) was used to determine significant differences between SRP, nitrate, nitrite, ammonia, temperature, turbidity, conductivity, $\mathrm{pH}$ and $\mathrm{DO}$ for the three sampling points of Cerrillos Reservoir. Pearson Correlation analyses were used to evaluate the possible correlations of SRP, nitrate, nitrite, ammonia, total coliforms with rainfall one week and two weeks prior sample collection. We also used Pearson Correlation to evaluate the possible relation of total coliforms with nutrient concentrations. Results were considered significant when a $p$-value was less than 0.05 . 


\section{Results}

\subsection{Rainfall Conditions}

Monthly rainfall ( $\mathrm{mm}$ ) for Cerrillos Reservoir recorded from June 2018 to January 2019 (Figure 2) indicated heavy rainfall during the month of August and allowed identification of specific rainfall events that occurred one and two weeks prior to water sample collection.

\subsection{Temperature, Turbidity, Conductivity, $\mathrm{pH}$, and Dissolved Oxygen}

Physicochemical parameters (Table 1) at Cerrillos Reservoir showed significant differences between temperature and turbidity for the three sampling points at the Cerrillos Reservoir (One Way ANOVA: $p=0.000$ and $p=0.005$, respectively) (Table 2). The inlet had the highest turbidity (6.1 NTU) and the lowest

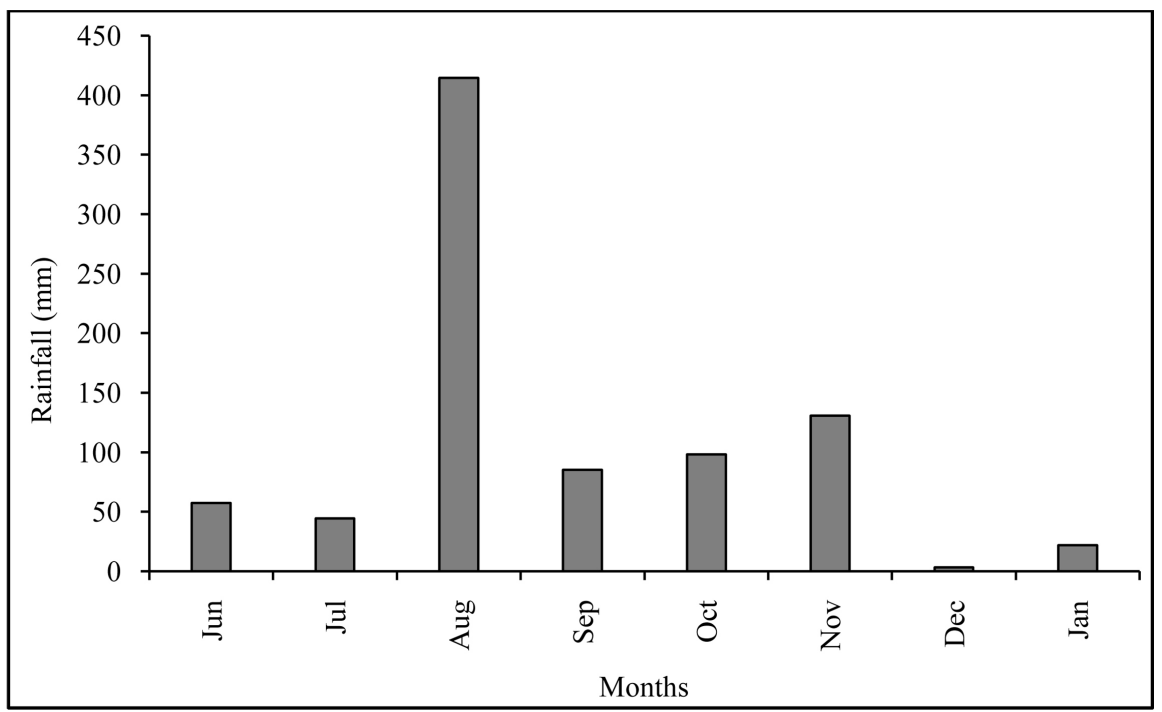

Figure 2. Total monthly rainfall for Cerrillos reservoir, from June 2018 to January 2019.

Table 1. Means of physicochemical parameters monitored from 15 May 2018 to 23 Jan 2019 at Cerrillos reservoir.

\begin{tabular}{cccccc}
\hline \multirow{2}{*}{ Location } & \multicolumn{5}{c}{ Physicochemical parameters } \\
\cline { 2 - 6 } & $\operatorname{Temp}\left({ }^{\circ} \mathrm{C}\right)^{\mathrm{a}}$ & $\begin{array}{c}\text { Turbidity } \\
(\mathrm{NTU})^{\mathrm{b}}\end{array}$ & $\begin{array}{c}\text { Conductivity } \\
(\mu \mathrm{S} / \mathrm{cm})^{\mathrm{c}}\end{array}$ & $\mathrm{pH}^{\mathrm{d}}$ & $\begin{array}{c}\mathrm{DO} \\
(\mathrm{mg} / \mathrm{L})^{\mathrm{e}}\end{array}$ \\
\hline Inlet & $25.0 \pm 2.2$ & $6.1 \pm 3.5$ & $241 \pm 41$ & $6.6 \pm 4.1$ & $7.5 \pm 0.3$ \\
Center & $27.8 \pm 0.6$ & $2.5 \pm 1.3$ & $249 \pm 53$ & $7.7 \pm 1.3$ & $7.5 \pm 1.1$ \\
Outlet & $27.7 \pm 0.7$ & $2.7 \pm 1.9$ & $259 \pm 15$ & $7.8 \pm 1.1$ & $7.1 \pm 1.0$ \\
\hline
\end{tabular}

(a) Temp: Temperature was measured with a YSI 556 Water Quality Sonde; (b) Turbidity: The turbidity was determined with a HACH 2100Q; $\left(^{c}\right)$ Conductivity: Conductivity was determined with a YSI 556 Water Quality Sonde; $\left({ }^{\mathrm{d}}\right) \mathrm{pH}$ : $\mathrm{pH}$ was determined with a HACH SL1000; $\left(^{e}\right)$ DO: Dissolved oxygen was determined with a YSI 556 Water Quality Sonde. 
Table 2. ANOVA for physicochemical parameters (temperature, turbidity, conductivity, $\mathrm{pH}$, and dissolved oxygen) for the three sampling points of Cerrillos reservoir $F$ and $p$ values determined via ANOVA.

\begin{tabular}{cccccc}
\hline \multicolumn{5}{c}{ Physicochemical parameters } \\
\cline { 2 - 6 } & Temp $\left({ }^{\circ} \mathrm{C}\right)$ & $\begin{array}{c}\text { Turbidity } \\
(\mathrm{NTU})\end{array}$ & $\begin{array}{c}\text { Conductivity } \\
(\mu \mathrm{S} / \mathrm{cm})\end{array}$ & $\mathrm{pH}$ & $\mathrm{DO}(\mathrm{mg} / \mathrm{L})$ \\
\hline \multirow{2}{*}{ ANOVA } & $F=11.80$, & $F=6.68$, & $F=0.89$, & $F=2.67$, & $F=0.52$, \\
& $p=0.000$ & $p=0.005$ & $p=0.423$ & $p=0.090$ & $p=0.602$ \\
\hline
\end{tabular}

temperature $\left(25.0^{\circ} \mathrm{C}\right)$. For conductivity, $\mathrm{pH}$ and $\mathrm{DO}$ there were no significant differences between sampling points (One Way ANOVA: $p=0.423, p=0.090$ and $p=0.602$, respectively). Values for $\mathrm{pH}$ are considered optimal (according to regulatory guidelines) on all but two occasions, when the $\mathrm{pH}$ at the inlet sampling point was extremely acid (5.7 (July 24, 2018) and 1.6 (August 22, 2018)). Mean DO for the three sampling points ranged from 5.0 to $8.9 \mathrm{mg} / \mathrm{L}$. Mean temperatures for all locations ranged from $23.0^{\circ} \mathrm{C}$ to $28.6^{\circ} \mathrm{C}$, and conductivity ranged from 172 to $271(\mu \mathrm{S} / \mathrm{cm})$.

\subsection{Phosphorus (P) and Nitrogen (N) Concentrations in the Cerrillos Reservoir}

SRP (Soluble Reactive Phosphorus) ranged between $37 \mu \mathrm{g} / \mathrm{L}$ and $243 \mu \mathrm{g} / \mathrm{L}$ (Figure 3). SRP showed significant differences for the three sampling points (One Way ANOVA: $p=3.94$ and $p=0.028$, respectively) (Table 3 ). Nitrite concentrations were below the HACH SL1000 range $(0.005-0.6 \mathrm{mg} / \mathrm{L}$ or $5-600 \mu \mathrm{g} / \mathrm{L})$, except for one occasion in the center of Cerrillos Reservoir (May 15, $0.334 \mu \mathrm{g} / \mathrm{L}$ ). Nitrate and ammonia ranged between $0 \mu \mathrm{g} / \mathrm{L}$ to $6417 \mu \mathrm{g} / \mathrm{L}$ and $50 \mu \mathrm{g} / \mathrm{L}$ to $540 \mu \mathrm{g} / \mathrm{L}$, respectively (Figure 4 and Figure 5). For 10 samples, ammonia concentrations were below the instrument's (HACH SL1000) range (0.05 - $1.5 \mathrm{mg} / \mathrm{L}$ or $50-1500$ $\mu \mathrm{g} / \mathrm{L})$. Neither nitrate nor ammonia showed significant differences for the three sampling points (One Way ANOVA: $p=0.14$ and $p=0.057$ ) (Table 3). We do not have nitrate data for May 15 and May 29.

\subsection{Phosphorus (P), Nitrogen (N), and Total Coliforms Linkage with Heavy Rainfall Precipitation Events}

Neither SRP nor ammonia were significantly correlated with rainfall events at Cerrillos Reservoir (inlet, center, outlet) (Table 4). Nitrate at the outlet was significantly correlated with rainfall both one week before sampling, and two weeks before sampling ( $r=0.859, p=0.000$ for one week and $r=0.798, p=0.001$ for two weeks, respectively) (Table 4). Total coliforms at inlet, center and outlet were not significantly $(p>0.05)$ correlated with rainfall at one or two weeks prior to sample collection.

\subsection{Total Coliforms and E. coli}

Mean concentrations of total coliforms range between 23 MPN/100 and 994 


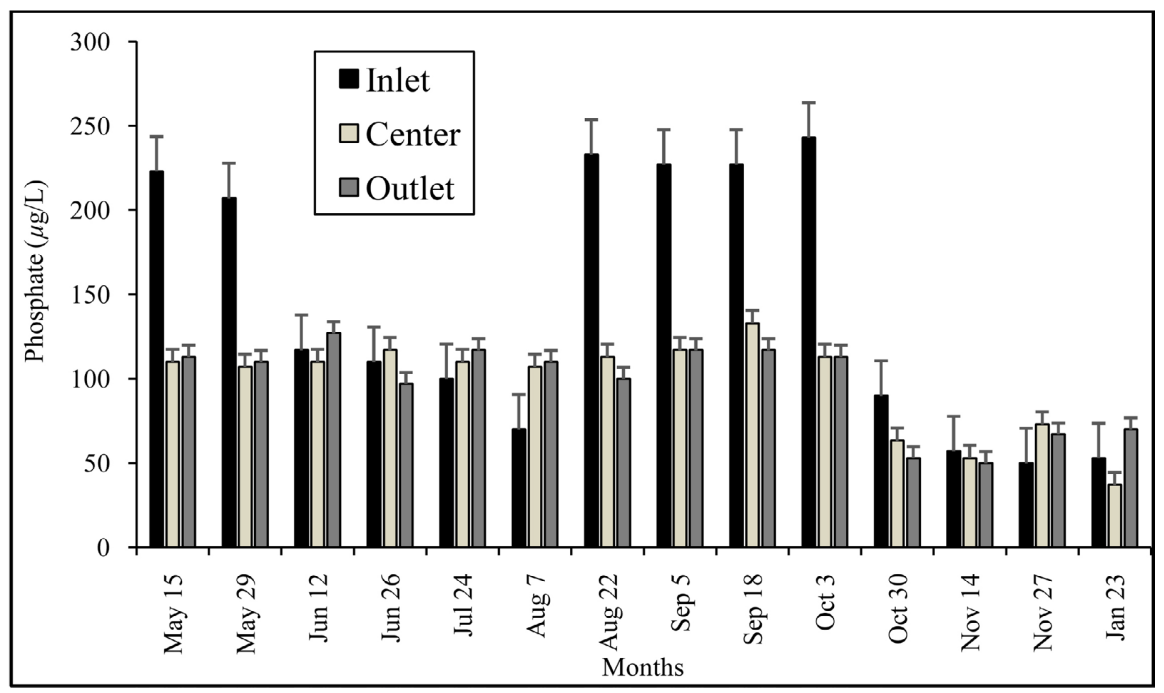

Figure 3. Phosphate concentrations $(\mu \mathrm{g} / \mathrm{L})$ from the inlet, center, and outlet of the Cerrillos reservoir from May 15, 2018 to January 23, 2019.

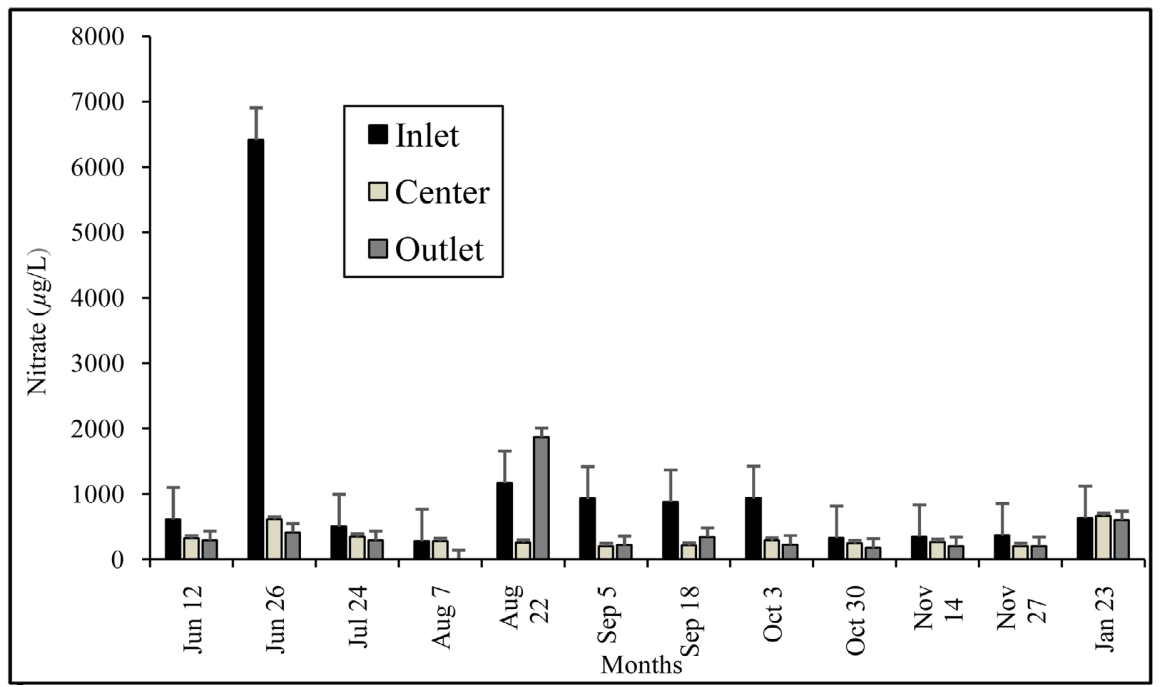

Figure 4. Nitrate concentrations $(\mu \mathrm{g} / \mathrm{L})$ from the inlet, center, and outlet of the Cerrillos reservoir from June 12, 2018 to January 23, 2019.

MPN/100 (Table 5). All water samples showed presence of E. coli (Table 5).

\subsection{Total Coliforms Linkage with Nutrient Concentrations}

Total coliforms were not significantly correlated with SRP, nitrate or ammonia $(p>0.05$ for each, Table 6).

\section{Discussion}

\subsection{Physico-Chemical Parameters}

Before hurricane Maria devasted Puerto Rico, the Puerto Rico 2016 305(b) and 303(d)Integrated Report indicated that the Cerrillos Reservoir was impaired by low dissolved oxygen and $\mathrm{pH}[16]$. 


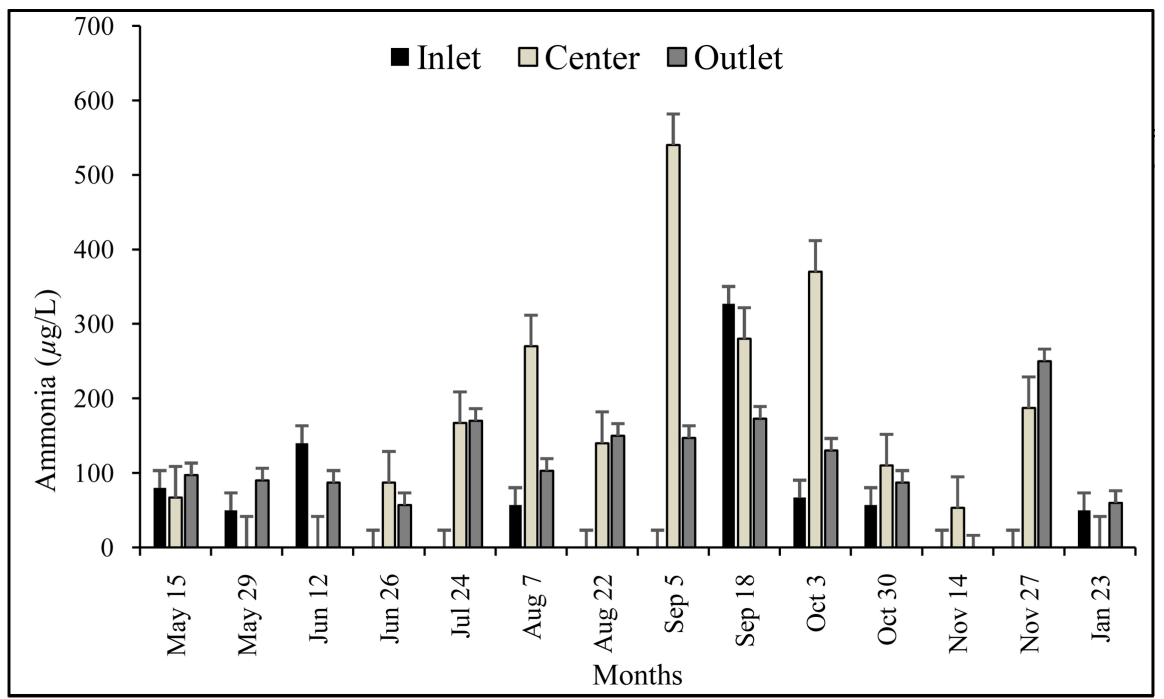

Figure 5. Ammonia concentrations $(\mu \mathrm{g} / \mathrm{L})$ from the inlet, center, and outlet of the Cerrillos reservoir from May 15, 2018 to January 23, 2019.

Table 3. ANOVA for SRP, nitrate, and ammonia for the three sampling points of Cerrillos reservoir. $F$ and $p$ values determined via ANOVA.

\begin{tabular}{cccc}
\hline & \multicolumn{3}{c}{ Nutrients } \\
\cline { 2 - 4 } & SRP & Nitrate $\left(\mathrm{NO}_{3}^{-}\right)$ & Ammonia $\left(\mathrm{NH}_{3}\right)$ \\
\hline ANOVA & $F=3.94, p=0.028$ & $F=2.07, p=0.140$ & $F=3.09, p=0.057$ \\
\hline
\end{tabular}

Table 4. Correlations ( $\mathrm{r}$ ) of Soluble Reactive Phosphorus (SRP), nitrate $\left(\mathrm{NO}_{3}^{-}\right)$, ammonia $\left(\mathrm{NH}_{3}\right)$, total coliforms at the Cerrillos Reservoir with rainfall events.

\begin{tabular}{ccccc}
\hline Rainfall & SRP & Nitrate & Ammonia \\
$\left(\mathrm{NO}_{3}^{-}\right)$ & $\left(\mathrm{NH}_{3}\right)$ & $\begin{array}{c}\text { Total } \\
\text { Coliforms }\end{array}$ \\
\hline \multirow{2}{*}{ One week prior } & $r^{b}=0.266$, & $r=0.103$, & $r=-0.201$, & $r=0.518$, \\
& $p^{c}=0.357$ & $p=0.727$ & $p=0.490$ & $p=0.233$ \\
Two weeks & $r=0.217$, & $r=0.046$, & $r=-0.211$, & $r=0.414$, \\
prior & $p=0.457$ & $p=0.877$ & $p=0.470$ & $p=0.356$ \\
& & & Center & \\
One week prior & $r=0.091$, & $r=-0.010$, & $r=0.065$, & $r=-0.158$, \\
Two weeks & $p=0.756$ & $p=0.972$ & $p=0.826$ & $p=0.738$ \\
prior & $p=0.101$, & $r=-0.080$, & $r=0.236$, & $r=-0.098$, \\
& & $p=0.785$ & $p=0.417$ & $p=0.834$ \\
One week prior & $r=-0.117$, & $r=0.859$, & $r=-0.002$, & $r=-0.212$, \\
Two weeks & $p=0.691$ & $p=0.000$ & $p=0.993$ & $p=0.648$ \\
prior & $r=-0.141$, & $r=0.798$, & $r=0.332$, & $r=-0.160$, \\
& $p=0.631$ & $p=0.001$ & $p=0.246$ & $p=0.731$ \\
\hline
\end{tabular}

aSoluble Reactive Phosphorus; ${ }^{b}$ Pearson correlation coefficient; ${ }^{c} p$-value for the correlation. 
Table 5. Mean of total coliforms.

\begin{tabular}{ccc}
\hline & \multicolumn{3}{c}{ Mean of MNPa $/ 100$} \\
\cline { 2 - 3 } Sampling & Total Coliforms & $\begin{array}{c}\text { E. coli } \\
\text { Presence }(+) / \text { Absence }(-)\end{array}$ \\
\hline 1 & 49 & + \\
2 & 52 & + \\
3 & 23 & + \\
4 & 994 & + \\
5 & 36 & + \\
6 & 367 & + \\
7 & 36 & + \\
\hline
\end{tabular}

${ }^{\mathrm{a} M o s t}$ probable number.

Table 6. Correlations of total coliforms with nutrient concentrations.

\begin{tabular}{cccc}
\hline \multirow{2}{*}{$\begin{array}{c}\text { Bacteriological } \\
\text { Parameters }\end{array}$} & \multicolumn{3}{c}{ Correlations } \\
\cline { 2 - 4 } Total Coliforms & & Nitrate $\left(\mathrm{NO}_{3}{ }^{-}\right)$ & Ammonia $\left(\mathrm{NH}_{3}\right)$ \\
\hline Inlet & $r^{b}=-0.518$, & $r=-0.327$, & $r=-0.346$, \\
& $p^{c}=0.234$ & $p=0.474$ & $p=0.447$ \\
Center & $r=0.131$, & $r=-0.123$, & $r=0.614$, \\
& $p=0.779$ & $p=0.793$ & $p=0.142$ \\
Outlet & $r=0.186$, & $r=-0.521$, & $r=0.161$, \\
& $p=0.689$ & $p=0.230$ & $p=0.730$ \\
\hline
\end{tabular}

a Soluble Reactive Phosphorus; ${ }^{b}$ Pearson correlation coefficient; ${ }^{c} p$-value for the correlation.

During our study, Cerrillos Reservoir did not exceed the parameters of temperature $\left(22.7^{\circ} \mathrm{C}-28.6^{\circ} \mathrm{C}\right)$, turbidity $(1.0 \mathrm{NTU}-10.2 \mathrm{NTU}), \mathrm{pH}(1.6-8.37)$ nor DO (5.0 to $8.9 \mathrm{mg} / \mathrm{L}$ ), established by the Puerto Rico Department of Natural and Environmental Resources (PRDNER). Water Quality Standards Regulations set by the PRDNER establish limits for surface waters to not exceed $30^{\circ} \mathrm{C}$ of temperature, not exceed $50 \mathrm{NTU}$ for turbidity, maintain a pH range of 6.0 to 9.0 and a DO of $5 \mathrm{mg} / \mathrm{L}$ or more [20]. PRDNER does not establish limits for conductivity but if for TDS (not exceed $500 \mathrm{mg} / \mathrm{L}$ ).) Conductivity increases with increasing ion content, which means that in most cases it provides a good approximation of TDS using the conversion factor of $1 \mathrm{mg} / \mathrm{L}(\mathrm{ppm})=2 \mu \mathrm{S} / \mathrm{cm} \mathrm{[21]}$. Thus, the conversion of conductivity to TDS revealed a range of $121 \mathrm{mg} / \mathrm{L}(\mathrm{ppm})$ to 130 $\mathrm{mg} / \mathrm{L}$ (ppm), which does not exceed the limit of $500 \mathrm{mg} / \mathrm{L}$.

SRP (inorganic P) ranged between $37 \mu \mathrm{g} / \mathrm{L}$ and $243 \mu \mathrm{g} / \mathrm{L}$ in the reservoir's surface water. Under natural conditions SRP concentrations usually are equivalent to about $5 \%-20 \%$ of total P concentration [22]. Total phosphorus concen- 
trations include organic and inorganic P. Total phosphorus shall not exceed 26 $\mu \mathrm{g} / \mathrm{L}$ in any reservoir or lake according to PRDNER [20]. Thus, we conclude that Cerrillos Reservoir showed a general behavior of eutrophic/hypereutrophic because total phosphorus concentrations of eutrophic and hypereutrophic lakes are between 30 to $100 \mu \mathrm{g} / \mathrm{L}$ and $>100 \mu \mathrm{g} / \mathrm{L}$, respectively [22].

Nitrate concentrations ranged between $0 \mu \mathrm{g} / \mathrm{L}$ to $6417 \mu \mathrm{g} / \mathrm{L}$, and nitrite concentrations were below the instrument's $(0.005-0.6 \mathrm{mg} / \mathrm{L}$ or $5-600 \mu \mathrm{g} / \mathrm{L})$, except for one occasion in the reservoir's (May 15, $0.334 \mu \mathrm{g} / \mathrm{L}$ ). Nitrite concentrations in the reservoir are low, and the presence of high dissolved oxygen (DO) may be oxidizing to nitrate. Ammonia range between $50 \mu \mathrm{g} / \mathrm{L}$ to $540 \mu \mathrm{g} / \mathrm{L}$, respectively. In general, the level of lake productivity due to inorganic nitrogen includes ultra-oligotrophic $(<200 \mu \mathrm{g} / \mathrm{L})$, oligo-mesotrophic $(200-400 \mu \mathrm{g} / \mathrm{L})$, meso-eutrophic $(300-650 \mu \mathrm{g} / \mathrm{L})$, eutrophic $(500-1500 \mu \mathrm{g} / \mathrm{L})$ and hypereutrophic $(>1500 \mu \mathrm{g} / \mathrm{L})$ [22]. Cerrillos Reservoir showed a general behavior of meso-eutrophic/eutrophic in relation with inorganic nitrogen. However, on two occasions we observed concentrations above $1500 \mu \mathrm{g} / \mathrm{L}$ (or hypereutrophic) for inorganic nitrogen. Sources of nitrogen in surface water include: 1) precipitation falling directly onto the lake surface, 2) nitrogen fixation both in the water and the sediments, and 3) inputs from surface and groundwater surface [22].

$\mathrm{N}$ and $\mathrm{P}$ concentrations in Cerrillos Reservoir were not sufficient to disrupt the balance of this ecosystem. This lake does not experience algal blooms, excessive aquatic plant growth or oxygen depletion. The deep lakes are less productive [23] and the hydrodynamic allowing the transport of sediments, toxics, and nutrients through Cerrillos Reservoir Lake geometry, vertical stratification, hydrological conditions, and meteorological conditions are factors that can influence the balance of ecosystems [23].

Reservoirs can be classified as riverine, transition and lacustrine zones [23]. The riverine zone is narrow, well mixed and shallow allowing an aerobic environment [23]. Also, in this zone advective forces transport significant quantities of finer particles, sediments, toxic substances and nutrients and light penetration is minimal [23]. In our study, the inlet (or the riverine zone) receives the input of the main river that provides water to the Cerrillos Reservoir, so it is expected that the natural flow regime affects other environmental factors including $\mathrm{pH}$, turbidity, temperature and SRP.

\subsection{Biological Parameters}

The total coliforms exceeded (23 MPN/100mL - $994 \mathrm{MPN} / 100 \mathrm{~mL}$ ) the parameter established for the Puerto Rico Water Quality Standards (PRWQS). For total coliforms, the PRWQS establishes that the median of the waters taken sequentially, shall not exceed $14 \mathrm{MPN} / 100 \mathrm{~mL}$, and not more than 10 percent of the samples shall exceed $43 \mathrm{MPN} / 100 \mathrm{~mL}$ [20]. Total coliform concentrations are considered to be hygiene indicators and in surface water imply the presence of bacterial genera Enterobacter, Escherichia, Klebsiella, and Citrobacter among 
others [24]. All water samples showed presence of $E$. coli, an indicator of recent fecal pollution [25] that can cause human diseases. Although, total coliforms were not significantly $(p>0.05)$ correlated with nutrients (SRP, nitrate and ammonia) it is important to note that the nutrients dissolved in the water help the microorganisms synthetize their main biomolecules, obtain energy and growth. After hurricane Maria, many reports presented an increase in conditions related to untreated water, including vomits, diarrhea, conjunctivitis, scabies, asthma, and leptospirosis [14].

\subsection{Phosphorus (P), Nitrogen (N) and Total Coliforms in Relation to Rainfall}

SRP, ammonia and total coliforms were not significantly $(p>0.05)$ correlated with rainfall events at Cerrillos Reservoir (inlet, center, outlet). During the study, Cerrillos Reservoir and its surrounding did not receive extreme precipitation events (more than $78 \mathrm{~mm}$ of rain per 24 hours in Puerto Rico (3 inches/24hours) [26]. Nitrate at the outlet was significantly correlated with both rainfall at one week before sampling, and two weeks before sampling ( $r=0.859, p=0.000$ for one week and $r=0.798, p=0.001$ for two weeks, respectively) due to nitrates are characterized by a high degree of mobility.

After hurricane Maria, the Puerto Rico 2018 305(b) and 303(d) Integrated Report presented that the causes of impairment at the Cerrillos Reservoir were low dissolved oxygen and Total Phosphorus [27]. The same report for 2020, added Total Nitrogen to the list of causes of impairment at the reservoir [17]. We conclude that after hurricane Maria, nutrient (phosphorus and nitrogen) concentrations at Cerrillos Reservoir have increased.

\section{Conclusions}

In this work, 3 monitoring sites were sampled from May 2018 to January 2019 in the Cerrillos Reservoir, Puerto Rico, with the objective of determining the water quality and the temporal and spatial variations of water quality variables including temperature, turbidity, conductivity, $\mathrm{pH}$, dissolved oxygen, phosphorus $(\mathrm{P})$ or Soluble Reactive Phosphorus (SRP), nitrogen (N) (nitrate, nitrite, and ammonia) and biological parameters (total coliforms and Escherichia coli). Analyses suggested that Cerrillos Reservoir has normal conditions of temperature, turbidity, conductivity, $\mathrm{pH}$, and dissolved oxygen. Current $\mathrm{P}$ and $\mathrm{N}$ concentrations are high, but the lake does not show symptoms of eutrophication.

Water quality, in terms of DO, has likely improved temporary in the aftermath of the hurricane. However, total coliforms exceeded the maximum levels (23 MPN/100mL - $994 \mathrm{MPN} / 100 \mathrm{~mL}$ ) established for the PRWQS as a consequence of the hurricane. Non-compliant coliform levels were not known prior to hurricane Maria, and therefore, we surmise that these high coliform levels are the result of the abrupt inflow of water to the reservoir from both stream flow and overland flow. In the case of coliforms, inputs of may include coliforms 
from disrupted septic systems as well as animal coliforms in overland flow from pastures (livestock, probably cattle). These disruptive impacts of the hurricane are a public health concern because the local human population has both primary and secondary contact with rivers, and reservoir's water and may still use it as a source of untreated drinking water. These disruptions may be temporary and will dissipate (or will already dissipate) or may continue.

Further investigation of Cerrillos Reservoir should be conducted and strengthened by sampling during at least one (annual) seasonal cycle. Such study also should compare the water quality of the two main tributaries that enter the reservoir, which lie in different catchment areas and conditions in southern Puerto Rico. Such studies may determine whether the disruption caused by the hurricane was temporary or the beginning of a new and ongoing trend. Also, we can investigate the potential sources of coliforms using caffeine as a possible indicator of human versus animal inputs.

\section{Acknowledgements}

We thank the many people contributed to this study during the fieldwork, laboratory analysis and data processing. We thank to Kiara Reyes, Kelvin Torres, Delimay Amaro and Antonio Salas for help in the lab and the field. We also wish to thank the Seed Money Program at Ponce Health Sciences University for providing materials, laboratory facilities and work/study opportunities for student dedication in this project. Thanks so much to EPA Caribbean Science Consortium for the availability of water sampling equipment. We also thank Mr. Gaspar Pons, Management Officer of the Natural Reserve of the Cerrillos Reservoir for assistance in the sampling process.

\section{Conflicts of Interest}

The authors declare no conflict of interest.

\section{References}

[1] Hamid, A., Bhat, S.U. and Jehangir, A. (2020) Local Determinants Influencing Stream Water Quality. Applied Water Science, 10, Article No. 24. https://doi.org/10.1007/s13201-019-1043-4

[2] Das, J., Karmaker, N. and Khan, R.A. (2021) Reasons and Consequences of River Water Pollution and Their Remediation: In Context of Bangladesh. GSC Advanced Research and Reviews, 7, 23-34. https://doi.org/10.30574/gscarr.2021.7.1.0066

[3] Al-Taai, S.H.H. (2021) Water Pollution: Its Causes and Effects. IOP Conferences Series: Earth and Environmental Science, 790, Article ID: 012026. https://doi.org/10.1088/1755-1315/790/1/012026

[4] Haseena, M., Malik, M.F., Javed, A., Arshad, S., Asif, N., Zulfiqar, S. and Hanif, J. (2017) Water Pollution and Human Health. Environmental Risk Assessment and Remediation, 1, 16-19. https://doi.org/10.4066/2529-8046.100020

[5] Mitiku, A.A. (2020) A Review on Water Pollution: Causes, Effects, and Treatment Methods. International Journal of Pharmaceutical Sciences Review and Research, 60, 94-101. 
[6] UN General Assembly (2015) The 2030 Agenda for Sustainable Development. https://sustainabledevelopment.un.org/content/documents/21252030\%20Agenda $\%$ 20for\%20Sustainable\%20Development\%20web.pdf

[7] Ho, L.T. and Goethals, P.L.M. (2019) Opportunities and Challenges for the Sustainability of Lakes and Reservoirs in Relation to the Sustainable Development Goals (SDGs). Water, 11, Article No. 1462. https://doi.org/10.3390/w11071462

[8] Hayes, N.M., Deemer, B.R., Corman, J.R., Razavi, N.R. and Strock, K.E. (2017) Key Differences between Lakes and Reservoirs Modify Climate Signals: A Case for a New Conceptual Model. Limnology and Oceanography Letter, 2, 47-62. https://doi.org/10.1002/lol2.10036

[9] Ghazal, N.K. and Salman, S.R. (2015) Determining the Optimum Site of Small Dams Using Remote Sensing Techniques and GIS. International Journal of Scientific Engineering and Research, 3, 69-73. https://www.ijser.in/archives/v3i9/IJSER15472.pdf

[10] Sayl, K.N., Muhammad, N.S., Yaseen, Z.M. and El-Shafie, A. (2016) Estimation the Physical Variables of Rainwater Harvesting System Using Integrated GIS-Based Remote Sensing Approach. Water Resources Management, 30, 3299-3313. https://doi.org/10.1007/s11269-016-1350-6

[11] Grill, G., Lehner, B., Thieme, M., Geenen, B., Tickner, D., Antonelli, F., Zarfl, C. (2019) Mapping the World's Free-Flowing Rivers. Nature, 569, Article ID: 215-221. https://doi.org/10.1038/s41586-019-1111-9

[12] Luhunga, P., Chang'a, L. and Djolov, G. (2017) Assessment of the Impacts of Climate Change on Maize Production on the Wami Ruvu Basin of Tanzania. Journal of Water and Climate Change, 1, 142-164. https://doi.org/10.2166/wcc.2016.055

[13] Mujere, N. and Moyce, W. (2018) Climate Change Impacts on Surface Water Quality. In: Khosrow-Pour, M., Ed., Hydrology and Water Resources Management. Breakthroughs in Research and Practice, IGI Global, Pennsylvania, 97-115. https://doi.org/10.4018/978-1-5225-3427-3.ch004

[14] Dorell, O. and Nunez, A. (2017) Puerto Rico's Water Woes Raise Fears of Health Crisis Six Weeks after Hurricane Maria. USA Today.

https://www.usatoday.com/story/news/world/2017/11/02/puerto-rico-water-woes-r aise-fears-health-crisis-six-weeks-afterhurricane-maria/808672001

[15] Ríos Dávila, R.A. (2018) La Autoridad de Acueductos y Alcantarillados (AAA): Historia de una catástrofe. Revista de Administración Pública, 49, 87-94.

[16] Puerto Rico Environmental Quality Board (2016) Puerto Rico 2016 305(b) and 303(d) Integrated Report.

https://www.epa.gov/sites/default/files/2017-01/documents/puerto rico $2016 \mathrm{impa}$ ired waters list.pdf

[17] Puerto Rico Environmental Quality Board (2021) Puerto Rico 2020 305(b) and 303(d) Integrated Report.

https://www.epa.gov/sites/default/files/2021-01/documents/puerto_rico 2020 303d list.pdf

[18] Kröger, R., Wes Neal, J. and Munoz, M. (2010) Spatial and Temporal Changes in Nutrients and Water Quality Parameters in Four Puerto Rico Reservoirs: Implications for Reservoir Productivity and Sport Fisheries Restoration. Mississippi Water Resources Conference, Bay St. Louis, 3-5 November 2010, 35-47.

[19] Soler-López, L.R. (2011) Sedimentation Survey of Lago Cerrillos, Ponce, Puerto Rico, April-May 2008. https://pubs.usgs.gov/sir/2011/5057/SIR2011 5057.pdf https://doi.org/10.3133/sir20115057

[20] Department of Natural and Environmental Resources (2019) Puerto Rico Water 
Quality Standards Regulation.

https://www.epa.gov/sites/default/files/2014-12/documents/prwqs.pdf

[21] YSI Inc. (2021) Water Hardness. https://www.ysi.com/water-hardness

[22] Wetzel, R.G. (2001) Limnology: Lake and River Ecosystems. Academic Press Elsevier, San Diego.

[23] Ji, Z.G. (2017) Hydrodynamics and Water Quality. John Wiley \& Sons, Hoboken. https://doi.org/10.1002/9781119371946

[24] Tominaga, T. and Ishii, M. (2020). Detection of Microorganisms with Lateral Flow Test Strips. In: Pavia, C.S. and Gurtler, V., Eds., Methods in Microbiology, Elsevier, Amsterdam, 351-394. https://doi.org/10.1016/bs.mim.2019.11.007

[25] Jang, J., Hur, H.G., Sadowsky, M.J., Byappanahalli, M.N., Yan, T. and Ishii, S. (2017) Environmental Escherichia coli: Ecology and Public Health Implications-A Review. Journal of Applied Microbiology, 123, 570-581.

https://doi.org/10.1111/jam.13468

[26] Puerto Rico Coastal Zone Management Program, Department of Natural and Environmental Resources, NOAA Office of Ocean, and Coastal Resource Management. Climate 2010-2013: Assessing Puerto Rico's Social-Ecological Vulnerabilities in a Changing Climate.

http://pr-ccc.org/download/PR\%20State\%20of\%20the\%20Climate-FINAL ENE201 5.pdf

[27] Puerto Rico Environmental Quality Board (2018) Puerto Rico 2016 305(b) and 303(d) Integrated Report.

https://www.epa.gov/sites/default/files/2019-01/documents/2018 final 303d list.pdf 